\title{
PENGARUH KINETIN DAN NAA TERHADAP INDUKSI KALUS PULE PANDAK (Rauvolfia serpentina (L.) Benth. ex Kurz)
}

\section{The Effect of Kinetin and NAA on Callus Induction of Pule Pandak (Rauvolfia serpentina (L.) Benth. ex Kurz)}

\author{
Heru Sudrajad ${ }^{1}$, Nur Rahmawati Wijaya ${ }^{1}$ \\ ${ }^{1}$ Balai Besar Penelitian dan Pengembangan Tanaman Obat dan Obat Tradisional \\ JL. Lawu no 11 Tawangmangu, Karanganyar. Jawa Tengah, Indonesia \\ *e-mail: herub2p2to2t@gmail.com
}

\begin{abstract}
Pule pandak is a rare medicinal plant with low regeneration since it only depends on natural propagation. This plant is difficult to be propagated while the demand of its material for herbal and pharmaceutical industries increased by time. The aim of this research was to find the best method of pule pandak callus induction. This research used pule pandak leaves as explant and Nitsch as base media. The experiment conducted using combination of Kinetin and NAA as growth hormones. The hormones concentration as follows: Kinetin $1 \mathrm{mg} / \mathrm{l}, 2 \mathrm{mg} / \mathrm{l}$, Kinetin $3 \mathrm{mg} / \mathrm{l}$ and $N A A$ concentration were $0 \mathrm{mg} / \mathrm{ml}$ (control) and $1 \mathrm{mg} / \mathrm{l}$. The results showed that the treatment of growth regulators combination of Kinetin $2 \mathrm{mg} / \mathrm{l}+N A A 0 \mathrm{mg} / \mathrm{l}$, Kinetin $2 \mathrm{mg} / \mathrm{l}+N A A 1 \mathrm{mg} / \mathrm{l}$, Kinetin $3 \mathrm{mg} / \mathrm{l}+N A A 0 \mathrm{mg} / \mathrm{l}$ and Kinetin 3 $\mathrm{mg} / \mathrm{l}+\mathrm{NAA} 1 \mathrm{mg} / \mathrm{l}$ were able to induce callus on $R$. serpentina explant while treatment of kinetin $3 \mathrm{mg} / \mathrm{l}$ and NAA $1 \mathrm{mg} / \mathrm{l}$ induced callus and roots.
\end{abstract}

Keywords: Rauvolfia serpentina, callus induction, kinetin, naphtalene acetic acid

\begin{abstract}
ABSTRAK
Pule pandak merupakan salah satu tanaman obat langka yang regenerasinya lambat karena hanya mengandalkan perbanyakan secara alami. Tumbuhan ini sulit dibudidayakan sementara kebutuhan sebagai bahan baku dalam industri herbal dan farmasi semakin meningkat. Penelitian ini bertujuan untuk mengetahui perlakuan terbaik untuk pembentukan kalus pule pandak. Dalam penelitian ini digunakan daun pule pandak sebagai eksplan dengan media dasar Nitsch dengan pemberian zat pengatur tumbuh kinetin dengan konsentrasi 1,2 dan $3 \mathrm{mg} / \mathrm{l}$ serta NAA konsentrasi $0 \mathrm{mg} / \mathrm{l}$ dan 1 $\mathrm{mg} / \mathrm{l}$. Hasil penelitian menunjukkan bahwa perlakuan zat pengatur tumbuh kombinasi kinetin $2 \mathrm{mg} / \mathrm{l}$ dan $3 \mathrm{mg} / \mathrm{l}$ serta NAA $1 \mathrm{mg} / \mathrm{l}$ dan NAA $0 \mathrm{mg} / \mathrm{l}$ mampu menginduksi kalus pada eksplan $R$. serpentina, sementara kombinasi kinetin $3 \mathrm{mg} / \mathrm{l}$ dan NAA $1 \mathrm{mg} / \mathrm{l}$ mampu menginduksi pertumbuhan kalus dan akar.
\end{abstract}

Kata kunci: Rauvolfia serpentina, induksi kalus, kinetin, naphtalene acetic acid

\section{PENDAHULUAN}

Pule pandak (Rauvolfia serpentina (L.) Benth. ex Kurz) merupakan tumbuhan anggota familia Apocynaceae. Tumbuhan ini mengandung senyawa kimia berupa reserpin, yohimbin, serpentin, deserpidin, ajmalicin dan ajmalin (Kumar et al., 2011; Pandey, Cherian, \& Patani, 2010). Khasiat dari tumbuhan $R$. serpentina antara lain sebagai antidiare, antikanker, antidisentri, depresan sistem saraf pusat, dan penangkal gigitan reptil beracun (Ezeigbo et al., 2012). Bagian akar tumbuhan pule pandak diketahui berperan sebagai obat penenang dan antihipertensi (Rathi et al., 2013). 
CITES telah menyatakan bahwa $R$. serpentina termasuk dalam Appendix II yang berarti tumbuhan tersebut tidak terancam punah namun bila terus diperdagangkan tanpa kontrol akan mengalami kepunahan (CITES, 2019). Sementara itu menurut IUCN tumbuhan ini telah masuk ke dalam status terancam punah (Kunwar, 2019). Menurut Sulandjari (2008) pule pandak dinyatakan mulai berkurang karena pengambilannya secara langsung dari habitat tanpa memperhatikan daya regenerasinya. Keberadaan tanaman pule pandak yang masih bersifat liar sudah semakin sulit ditemukan. Hal ini disebabkan R. serpentina sukar untuk dibudidayakan, sementara kebutuhan bahan baku obat yang berasal dari tanaman ini untuk industri jamu dan farmasi terus meningkat. Laju pemanenan di alam lebih cepat dari laju kemampuan alam dalam memulihkan populasinya (Zakaria, 2010). Kebutuhan akar untuk pembuatan ekstrak diperkirakan hampir 650 ton pertahun sedangkan penggunaan simplisia dalam negeri mengalami kecenderungan meningkat sebesar 25,89\% pertahun (Sulandjari, 2008; Yahya, 2001).

Selama ini perbanyakan pule pandak hanya mengandalkan biji yang diperoleh dari alam dan usaha budidaya pule pandak masih rendah. Pertumbuhan biji dan stek batang menghasilkan pertumbuhan kurang dari 15\% sehingga hasil yang diperoleh belum memenuhi kebutuhan konsumen (Elfa dkk., 2019; Khisbah, 2003). Akibat rendahnya hasil budidaya secara konvensional maka dibutuhkan upaya budidaya lain yang lebih efektif. Salah satu upaya yang dapat dilakukan adalah melalui kultur jaringan.

Teknik kultur jaringan dapat mengatasi kendala dalam produksi bibit. Setiap tanaman jika diperlakukan dengan zat pengatur tumbuh akan memberikan reaksi yang berbeda-beda. Kombinasi antara zat pengatur tumbuh dan media dasar yang tepat dapat meningkatkan pembelahan sel dalam proses morfogenesis dan organogenesis (Lestari, 2011). Pemberian dosis zat pengatur tumbuh dalam jumlah yang tepat perlu dilakukan untuk memperoleh hasil terbaik. Pemberian zat pengatur tumbuh secara kombinasi lebih efektif merangsang pertumbuhan daripada diberikan secara tunggal pada konsentrasi yang sama.

Pemberian auksin maupun sitokinin ke dalam media kultur dapat meningkatkan konsentrasi zat pengatur tumbuh endogen yang telah terdapat di dalam sel sehingga menjadi pemicu pertumbuhan jaringan (Gunawan, 1992; Sulichantini, 2016). Hormon kinetin termasuk turunan dari hormon sitokinin yang berfungsi untuk memacu pembelahan sel. NAA merupakan zat pengatur tumbuh dari golongan auksin yang berperan dalam pemanjangan sel dan morfogenesis tanaman. Manipulasi pemberian dosis auksin dan sitokinin dapat menghasilkan pertumbuhan tunas (Poonspaya, 1989 dalam (Lestari, 2011). Penelitian yang dilakukan oleh Yunita \& Lestari, (2011) menyebutkan bahwa penggunaan kombinasi BAP 0,5 mg/l dan thidiazuron $0,2 \mathrm{mg} / \mathrm{l}$ menghasilkan pertumbuhan tunas pule pandak sedangkan penelitian yang dilakukan oleh Sugito et al., (2006) pada tanaman yang sama menunjukkan bahwa pemberian kombinasi thidiazuron 6 ppm dan 2,4 D 0,5 ppm menghasilkan pertumbuhan kalus. Dengan dilakukannya penelitian ini diharapkan dapat dihasilkan kalus pule pandak yang akan berkembang menjadi tunas sehingga menghasilkan bibit yang dapat digunakan untuk memenuhi kebutuhan bahan baku obat.

\section{METODE}

Bahan yang digunakan yaitu daun pule pandak ( $R$. serpentina), kinetin, NAA, detergen, fungisida, bakterisida, desinfektan dan, bahan kimia penyusun media Nitsch. Alat yang digunakan autoklaf, laminair air flow (LAF), timbangan analitik, hotplate, pinset dan skalpel.

Penelitian dilakukan di Laboratorium Kultur Jaringan Tanaman Balai Besar Penelitian dan Pengembangan Tanaman Obat dan Obat Tradisional, Tawangmangu pada bulan Mei sampai Juli 2018. Eksplan yang digunakan berupa daun muda. Tanaman ini diambil dari kebun Balai Besar 
Penelitian dan Pengembangan Tanaman Obat dan Obat Tradisional Tawangmangu. Sterilisasi dilakukan dengan perendaman eksplan dalam detergen selama 3 menit kemudian dibilas dengan akuades steril sebanyak 3 kali. Selanjutnya dilakukan perendaman pada bakterisida 0,5\% selama 5 menit. Setelah dibilas dengan akuades steril sebanyak 3 kali, eksplan direndam fungisida selama 7 menit. Eksplan dibilas menggunakan akuades steril kemudian direndam dalam 2,125\% natrium hipoklorit selama 5 menit. Eksplan selanjutnya ditanam dalam media Nitsch dengan kombinasi zat pengatur tumbuh (ZPT). Penelitian menggunakan rancangan acak kelompok lengkap pola faktorial sebagai faktor pertama hormon kinetin konsentrasi 1, 2, $3 \mathrm{mg} / \mathrm{l}$ dan faktor kedua NAA konsentrasi 0 dan $1 \mathrm{mg} / \mathrm{l}$. Masing-masing ZPT dilakukan kombinasi dan perlakuan dibuat 3 kali ulangan masing-masing terdiri dari 10 botol. Penanaman dilakukan pada LAF yang sudah steril dengan media dan peralatan yang sudah disterilisasi menggunakan autoklaf. Eksplan diinkubasi selama 120 hari.

\section{HASIL DAN PEMBAHASAN}

Kalus merupakan proliferasi massa sel bersifat meristematik yang belum terdiferensiasi. Induksi kalus dapat dilakukan dengan penggunaan zat pengatur tumbuh auksin dan sitokinin atau kombinasi dari keduanya. Pertumbuhan kalus dipengaruhi oleh rasio seimbang dari konsentrasi kedua hormon tersebut sehingga dengan pemberian ZPT dalam konsentrasi yang tepat akan diperoleh kalus dengan hasil optimal (Kurniawan \& Widoretno, 2016).

Pengaruh pemberian kinetin dan NAA pada eksplan daun pule pandak ( $R$. serpentina) dilihat pada Tabel 1.

Tabel 1. Hasil pertumbuhan kalus pada eksplan daun R. serpentina pada media Nitsch masa inkubasi 120 hari

\begin{tabular}{lcccc}
\hline Perlakuan & $\begin{array}{c}\text { Waktu } \\
\text { Tumbuh } \\
\text { (hari) }\end{array}$ & $\begin{array}{c}\text { Pertumbuhan } \\
\text { Eksplan }\end{array}$ & $\begin{array}{c}\text { Diameter } \\
\text { Kalus } \\
\text { (mm) }\end{array}$ & $\begin{array}{c}\text { Tekstur dan } \\
\text { Warna Kalus }\end{array}$ \\
\hline Kinetin 1 mg/l + NAA 0 mg/l & - & Tetap & - & - \\
Kinetin 1 mg/l + NAA 1 mg/l & - & Tetap & - & - \\
Kinetin 2 mg/l + NAA 0 mg/l & 45 & Kalus + & 12 & Remah, Hijau Kecoklatan \\
Kinetin 2 mg/l + NAA 1 mg/l & 35 & Kalus ++ & 15 & Remah, Hijau Kecoklatan \\
Kinetin 3 mg/l + NAA 0 mg/l & 35 & Kalus ++ & 15 & Remah, Hijau Kecoklatan \\
Kinetin 3 mg/l + NAA 1 mg/l & 35 & Kalus ++ dan akar & 16 & Remah, Hijau Kecoklatan \\
\hline Keterangan: + = jumlah kalus sedikit, ++ = jumlah kalus cukup banyak; waktu tumbuh dihitung sejak masa inkubasi \\
eksplant sampai inisiasi terbentuknya kalus.
\end{tabular}

Tabel 1 menunjukkan bahwa perlakuan kinetin mulai konsentrasi $2 \mathrm{mg} / \mathrm{l}$ baik dengan kombinasi dan tanpa kombinasi dengan NAA efektif menghasilkan pertumbuhan kalus. Pemberikan kinetin dengan konsentrasi yang semakin meningkat tidak meningkatkan pertumbuhan kalus.

Banyaknya kalus selain diamati secara kualitatif juga dilakukan pengamatan secara kuantitatif melalui pengukuran diameter kalus. Hasil pengamatan diameter kalus menunjukkan bahwa pada perlakuan kinetin $3 \mathrm{mg} / \mathrm{l}$ dan NAA $1 \mathrm{mg} / \mathrm{l}$ menghasilkan kalus paling banyak dengan diameter paling besar yaitu $16 \mathrm{~mm}$, sedangkan perlakuan dengan pemberian kinetin dan NAA dalam konsentrasi rendah yaitu kinetin $1 \mathrm{mg} / \mathrm{l}$ belum mampu menginisiasi pertumbuhan kalus dari eksplan $R$. serpentina. Sementara itu pengamatan secara kualitatif menunjukkan bahwa perlakuan kinetin pada konsentrasi $2 \mathrm{mg} / \mathrm{l}$ dan $3 \mathrm{mg} / \mathrm{l}$ baik dengan kombinasi maupun tanpa kombinasi dengan NAA menghasilkan jumlah kalus lebih banyak yang ditandai dengan 
pertambahan diameter kalus. Hal tersebut menunjukkan bahwa konsentrasi kinetin $2 \mathrm{mg} / \mathrm{l}$ adalah konsentrasi paling rendah untuk memacu pertumbuhan eksplan dari $R$. serpentina.

Pada semua perlakuan zat pengatur tumbuh terhadap kalus $R$. serpentina yang berhasil tumbuh menunjukkan perkembangan yang mengarah pada pembentukan kalus. Dengan demikian eksplan tersebut akan berubah terlebih dahulu membentuk jaringan meristematik sebelum membentuk tunas dan akar. Perlakuan pada media Nitsch dengan hormon kinetin 2 mg/l dengan NAA $1 \mathrm{mg} / \mathrm{l}$ diperoleh kalus $R$. serpentina walaupun dalam jumlah sedikit sedangkan perlakuan dengan konsentrasi kinetin $1 \mathrm{mg} / \mathrm{l}$ dengan $\mathrm{NAA} 1 \mathrm{mg} / \mathrm{l}$ tidak menghasilkan kalus. Hasil tersebut berbeda dengan penelitian Kaviani et al., (2013) dengan menggunakan Aloe vera, penggunaan kinetin $2 \mathrm{mg} / \mathrm{l}$ dengan NAA $1 \mathrm{mg} / \mathrm{l}$ menghasilkan kalus sebanyak 34,7\% sedangkan konsentrasi yang lebih rendah kinetin $0.5 \mathrm{mg} / \mathrm{l}$ dengan NAA 0,5 mg/l menghasilkan kalus hingga 100\%.

Penggunaan kinetin dalam konsentrasi tinggi yaitu $3 \mathrm{mg} / \mathrm{l}$ menghasilkan pertumbuhan kalus yang lebih cepat (35 hari) dibandingkan kinetin pada konsentrasi lebih rendah. Penambahan zat pengatur tumbuh diperlukan untuk mendukung pertumbuhan eksplan dan membantu terbentuknya jaringan tertentu.
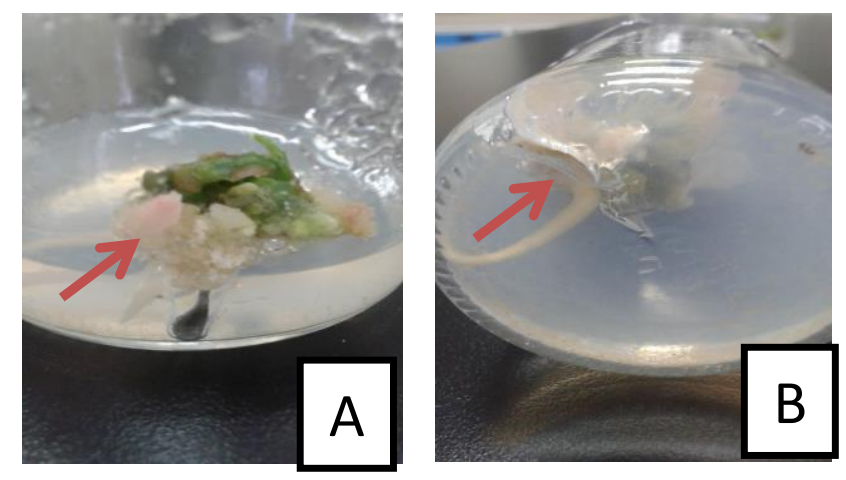

Gambar 1. Kalus dan akar R. serpentina media Nitsch pada hormon kinetin 2 mg/l dan NAA $1 \mathrm{mg} / \mathrm{l}$ (A), dan hormon kinetin $3 \mathrm{mg} / \mathrm{l}$ dan NAA $1 \mathrm{mg} / \mathrm{l}(\mathrm{B})$

Pada perlakuan kombinasi kinetin $2 \mathrm{mg} / \mathrm{l}$ dengan NAA $1 \mathrm{mg} / \mathrm{l}$ diperoleh hasil terbentuknya kalus (A) dan kombinasi kinetin $3 \mathrm{mg} / \mathrm{l}$ dengan NAA $1 \mathrm{mg} / \mathrm{l}$ menghasilkan pertumbuhan kalus dan akar dengan waktu tumbuh 35 hari setelah tanam (Gambar 1). NAA merupakan zat pengatur tumbuh dari golongan auksin yang berperan dalam pemanjangan sel dan morfognesis tanaman (Miryam \& Suliansyah, 2008). Auksin memiliki peran utama untuk pembentukan kalus dan morfogenesis, namun dengan adanya kombinasi dengan sitokinin yang juga berperan dalam pembelahan sel dan proliferasi kalus sehingga penambahan auksin dan sitokinin menghasilkan pertumbuhan kalus terbaik (Purnamaningsih \& Ashrina, 2011). Perlakuan kombinasi kinetin $1 \mathrm{mg} / \mathrm{l}$ dengan NAA $0 \mathrm{mg} / \mathrm{l}$ tidak menghasilkan kalus karena tidak adanya auksin sehingga pertumbuhan kalus terhambat. Hasil yang sama juga ditunjukkan pada perlakuan kombinasi kinetin $1 \mathrm{mg} / \mathrm{l}$ dan NAA $1 \mathrm{mg} / \mathrm{l}$ hal ini kemungkinan disebabkan karena sitokinin yang rendah.

Pengaruh auksin terhadap perkembangan sel menunjukkan adanya indikasi bahwa auksin dapat menaikkan tekanan osmotik, meningkatkan sintesa protein, meningkatkan permeabilitas sel terhadap air dan melunakkan dinding sel yang diikuti menurunnya tekanan dinding sel sehingga air dapat masuk ke dalam sel yang disertai dengan kenaikan volume sel (Hendaryono 
dalam Nisak, Nurhidayati, \& Purwani, 2012). NAA merupakan salah satu jenis zat pengatur tumbuh yang bersifat stabil dan memiliki mobilitas tinggi dalam tanaman. Zat ini tidak mudah diurai oleh enzim yang dikeluarkan sel maupun oleh pemanasan akibat sterilisasi dibandingkan auksin lainnya (Herawan \& B. Ismail, 2009; Suprapto, 2004).

Penelitian yang dilakukan oleh Nella (2017) menyatakan bahwa eksplan daun BangunBangun (Plectranthus amboinicus (Lour.) Spreng) yang dikulturkan dalam media MS dengan penambahan $3 \mathrm{mg} / \mathrm{l}$ NAA dan 0,1 mg/l kinetin dapat menginduksi akar. Sedangkan penelitian lain menunjukkan bahwa pemberian konsentrasi NAA 0,4 ppm dan kinetin 4 ppm merupakan perlakuan terbaik terhadap jumlah akar buah naga (Hylocereus costricensis) yaitu 5,2 (Mahadi et al., 2013).

Perbandingan antara auksin yang lebih tinggi dibandingkan sitokinin akan menghasilkan terbentuknya akar sedangkan sitokinin yang lebih tinggi akan menghasilkan pembentukan tunas. Apabila auksin dan sitokinin diberikan dalam jumlah seimbang maka akan menghasilkan pertumbuhan kalus dan sitokinin (Davies, 1995), Pada perlakuan kombinasi kinetin $3 \mathrm{mg} / \mathrm{l}$ dengan NAA $1 \mathrm{mg} / \mathrm{l}$ diperoleh hasil berupa akar. Hal ini kemungkinan disebabkan karena auksin yang diberikan dalam konsentrasi lebih tinggi dibandingkan sitokinin. Akar adventif pada umumnya muncul akibat adanya auksin. Transport auksin mampu mengontrol panjang akar tanaman, jumlah akar adventif, rambut akar dan arah tumbuh akar (Mishra et al., 2009). NAA sebagai auksin sintetis dalam konsentrasi rendah sudah dapat memberikan respon pertumbuhan sel, pembelahan sel dan pembentukan akar (Sun \& Hong, 2010) namun pada penelitian ini NAA menghasilkan akar pada konsentrasi $3 \mathrm{mg} / \mathrm{l}$.

Warna kalus dapat menjadi salah satu indikator kualitas kalus yang dihasilkan. Menurut Andaryani (2010) kalus yang baik memiliki warna hijau, sedangkan kalus berwarna putih menunjukkan bahwa kodisi kalus masih cukup baik. Hasil penelitian menunjukkan bahwa semua eksplan menghasilkan kalus berwarna hijau kecoklatan. Kalus berwarna kecoklatan menunjukkan bahwa pertumbuhan kalus mengalami penurunan akibat metabolisme senyawa fenol. Dalam konsentrasi berlebihan, fenol bersifat toksik bagi sel sehingga akan menghambat pertumbuhan sedangkan dalam konsentrasi terbatas masih dapat ditoleransi sehingga masih dapat tumbuh (Hayati \& Nurchayati, 2010).

Hasil pertumbuhan kalus dan kalus berakar pada eksplan $R$. serpentina dengan perlakuan kombinasi hormone kinetin dan NAA pada penelitian ini dapat dijadikan dasar pengembangan produksi bibit pule pandak secara kultur jaringan. Penelitian lebih lanjut masih sangat diperlukan untuk mentransformasi kalus yang telah terbentuk dari eksplan daun $R$ serpentina menjadi tunas berakar sehingga mampu menjadi bibit untuk bahan perbanyakan. Mengingat regenerasi secara generatif tanaman $R$. serpentina di alam sangat lambat maka teknologi kultur jaringan diperlukan guna mengatasi ketersediaan bibit dalam jumlah besar dan berkualitas.

\section{KESIMPULAN}

Penggunaan zat pengatur tumbuh BAP pada konsentrasi $2 \mathrm{mg} / \mathrm{l}$ dan $3 \mathrm{mg} / \mathrm{l}$ yang dikombinasikan atau tanpa dikombinasikan dengan NAA mampu menginisiasi pembentukan kalus eksplan daun pule pandak (Rauvolfia serpentina (L.) Benth. ex Kurz) yang dikulturkan pada media Nitsch. Penggunaan zat pengatur tumbuh BAP pada konsentrasi $3 \mathrm{mg} / \mathrm{l}$ yang dikombinasikan dengan NAA $1 \mathrm{mg} / \mathrm{l}$ dhasilkan kalus dan akar pada eksplan daun pule pandak. 


\section{UCAPAN TERIMA KASIH}

Ucapan terimakasih penulis sampaikan kepada Kepala Balai Besar Penelitian dan Pengembangan Tanaman Obat dan Obat Tradisional serta peneliti sehingga penelitian ini dapat selesai dengan hasil seperti yang diharapkan.

\section{DAFTAR PUSTAKA}

Andaryani, S. (2010). Kajian Penggunaan Berbagai Konsentrasi BAP dan 2,4-D terhadap Induksi Kalus Jarak Pagar (Jatropha curcas L.) secara In Vitro. Skripsi. Fakultas Pertanian Universitas Sebelas Maret.

CITES. (2019). Appendices I, II and III, Interpretation valid from 26 November 2019. Retrieved from https://www.cites.org/eng/app/appendices.php. Diakses 27 November 2019.

Davies, P. J. (1995). Plant Hormones-Physiology, Biochemistry and Molecular Biology. Kluwer Academic Publisher.

Elfa, M., Aufa, I. A., Chaidir, L., \& Dikayani. (2019). Pengaruh Kombinasi Zat Pengatur Tumbuh Benzyl Amino Purin ( BAP) dan Naphthalene Acetic Acid ( NAA) terhadap Pertumbuhan Pule Pandak ( Rauvolfia serpentina (L.) Benth . ex Kurz .) secara In Vitro. Prosiding Seminar Nasional Agroteknologi, 7:11-719.

Ezeigbo, I. I., Ezeja, M. I., Madubuike, K. G., Ifenkwe, D. C., Ukweni, I. A., Udeh, N. E., \& Akomas, S. C. (2012). Antidiarrhoeal Activity of Leaf Methanolic Extract of Rauwolfia serpentina. Asian Pacific Journal of Tropical Biomedicine, 2(6), 430-432. https://doi.org/10.1016/S22211691(12)60070-7.

Gunawan. (1992). Teknik Kultur Jaringan Tumbuhan. Bogor: Departemen Pendidikan dan Kebudayaan, Direktorat Jenderal Pendidikan Tinggi, Pusat Antar Universitas Bioteknologi IPB.

Hayati, S. K., \& Nurchayati, Y. (2010). Induksi Kalus dari Hipokotil Alfalfa (Medicago sativa l.) secara In Vitro dengan Penambahan Benzyl Amino Purine (BAP) dan $\alpha$-Naphtalene Acetic Acid (NAA). Bioma - Berkala Ilmiah Biologi, 12(1), 6-12. https://doi.org/10.14710/bioma.12.1.6-12

Herawan, T., \& B. Ismail. (2009). Penggunaan Kombinasi Auksin dan Sitokinin untuk Menginduksi Tunas pada Kultur Jaringan Sengon (Falacataria moluccana) Menggunakan Bagian Kotiledon. Jurnal Pemuliaan Tanaman Hutan, 3(1), 23-31.

Kaviani, B., Hesar, A. A., Tarang, A., \& Zanjani, S. B. (2013). Effect of Kinetin (Kn) and Naphthalene Acetic Acid (NAA) on The Micropropagation of Matthiola incana using Shoot Tips, and Callus Induction and Root Formation on the Leaf Explants. African Journal of Agricultural Research, 8(30), 4134-4139. https://doi.org/10.5897/AJAR11.921

Khisbah, A. (2003). Potensi Tumbuhan Obat Pule Pandak (Rauvolvia serpentina Benth.) di RPH Selogender, BKPH Selogender KPH Randuplatung. Skripsi. Institut Pertanian Bogor.

Kumar, C. ., Bindu, S., Chitra, C. R., \& Mathew, P. J. (2011). Taxonomic Significance of Fruit and Seed Morphology in Identification of South Indian Rauvolfia (Apocynaceae). Rheedea, 21(2), 160166.

Kunwar, B. B. (2019). Establishing In Situ Gene Bank of Rauvolfia serpentina ( L .) Benth ex Kurtz in Western Nepal with A Focus on Conservation and Sustainability. Biodiversity International Journal Research, 3(4), 139-143. https://doi.org/10.15406/bij.2019.03.00138.

Kurniawan, A. D., \& Widoretno, W. (2016). Regenerasi In Vitro Tanaman Bawang Merah (Allium ascalonicum L.). Jurnal Biotropika, 4(1), 1-4.

Lestari.E.G. (2011). Peranan Zat Pengatur Tumbuh dalam Perbanyakan Tanaman melalui Kultur Jaringan The Role of Growth Regulator in Tissue Culture Plant. Jurnal Agrobiogen, 7(1), 63-68.

Mahadi, I., Wulandari, S., \& Trisnawati, D. (2013). Pengaruh Pemberian NAA dan Kinetin Terhadap Pertumbuhan Eksplan Buah Naga (Hylocereus costaricensis) Melalui Teknik Kultur Jaringan 
Secara In Vitro. Jurnal Biogenesis, 9(2), 14-20. Retrieved from http://www.albayan.ae.

Miryam, A., \& Suliansyah, I. (2008). Multiplikasi Jeruk Kacang (Citrus nobilis L.) pada Beberapa Konsentrasi NAA dan BAP pada Media WPM secara In Vitro. Jerami, 1(2), 1-8.

Mishra, B. S., Singh, M., Aggrawal, P., \& Laxmi, A. (2009). Glucose and auxin signaling interaction in controlling Arabidopsis thaliana seedlings root growth and development. Plos One, 4(2), 1-13. https://doi.org/10.1371/journal.pone.0004502.

Nella, S. ., Siregar, L. A. M., \& PUTRI, L. A. P. (2017). Pengaruh Zat Pengatur Tumbuh terhadap Induksi Akar (Rhizogenesis) pada Tanaman Bangun-Bangun (Plectranthus amboinicus (Lour.) Spreng) secara In Vitro. Jurnal Agroteknologi, 5(3), 644-649.

Nisak, K., Nurhidayati, T., \& Purwani, K. I. (2012). Pengaruh Kombinasi konsentrasi ZPT NAA dan BAP pada Kultur Jaringan Tembakau Nicotiana tabacum var. Prancak 95. Jurnal Sains dan Seni Pomits, 1(1), 1-6.

Pandey, V. P., Cherian, E., \& Patani, G. (2010). EffEct of Growth Regulators and Culture Conditions on Direct Root Induction of Rauwolfia serpentina L. (Apocynaceae) Benth by Leaf Explants. Tropical Journal of Pharmaceutical Research, 9(1), 27-34. https://doi.org/10.4314/tjpr.v9i1.52031

Purnamaningsih, R., \& Ashrina, M. (2011). Pengaruh BAP dan NAA terhadap Induksi Kalus dan Kandungan Artemisinin dari Artemisia annua L. 1 [The Effect of BAP and NAA on Callus Induction and Artemisinin Content of Artemisia annua L.]. Berita Biologi, 10(4), 481-489.

Rathi, P., Kumari, R., Rajput, C. S., \& Sawhney, S. S. (2013). Therapeutic Characterstics of Rauwolfia serpentina. International Journal of Pharmaceutical and Chemical Sciences, 2(2), 1038-10422.

Sugito, H., Santosa, Y., \& Sandra, E. (2006). Penggunaan Thidiazuron, 2,4-D dan Giberellin dalam Pembentukan Embrio Somatik Pule Pandak (Rauvolfia serpentina (L.) Benth. ex Kurz) melalui Kultur In Vitro. Media Konservasi, 11(2), 66-71.

Sulandjari. (2008). Root Yield and Reserpine Content of Rauvolfia serpentina Benth. on Media Under the Plant with Allelopathic Potentiality with Nutrient Addition. Biodiversitas, Journal of Biological Diversity, 9(3), 180-183. https://doi.org/10.13057/biodiv/d090306

Sulichantini, E. D. (2016). Pengaruh Konsentrasi Zat Pengatur Tumbuh terhadap Regenerasi Bawang Putih (Allium sativum L.). Jurnal Agrifor, 17(1), 29-36.

Sun, Y. L., \& Hong, S. K. (2010). Effects of plant growth regulators and l-glutamic acid on shoot organogenesis in the halophyte Leymus chinensis (Trin.). Plant Cell, Tissue and Organ Culture, 100(3), 317-328. https://doi.org/10.1007/s11240-009-9653-4

Suprapto, A. (2004). Tanaman Bebas Virus. Jurnal UTD, 21(1), 81-90.

Yahya, F. A. (2001). Pertumbuhan, Biomassa dan Kandungan Alkaloid Akar Pulepandak (Rauwolfia serpentina Benth.).Skripsi Fakultas Kehutanan.Institut Pertanian Bogor.

Yunita.R, \& Lestari.E.G. (2011). Perbanyakan Tanaman Pulai Pandak ( Rauwolfia serpentina L .) dengan Teknik Kultur Jaringan. Jurnal Natur Indonesia, 14(65), 68-72.

Zakaria, D. (2010). Pengaruh Konsentrasi Sukrosa dan BAP (Benzil Amino Purin) dalam Media Murashige Skoog (MS) terhadap pertumbuhan dan Kandungan Reserpin Kalus Pule Pandak (Rauvolfia verticillata Lour.).Skripsi.Fakultas MIPA.Universitas Sebelas Maret. 